\title{
Video Article \\ Isolation of Retinal Stem Cells from the Mouse Eye
}

\author{
Brenda L.K. Coles ${ }^{1}$, Derek van der Kooy ${ }^{1}$ \\ ${ }^{1}$ Molecular Genetics, University of Toronto
}

Correspondence to: Brenda L.K. Coles at brenda.coles@utoronto.ca

URL: https://www.jove.com/video/2209

DOI: doi:10.3791/2209

Keywords: Cellular Biology, Issue 43, Stem Cells, Eye, Ciliary Epithelium, Tissue Culture, Mouse

Date Published: 9/11/2010

Citation: Coles, B.L., van der Kooy, D. Isolation of Retinal Stem Cells from the Mouse Eye. J. Vis. Exp. (43), e2209, doi:10.3791/2209 (2010).

\section{Abstract}

The adult mouse retinal stem cell (RSC) is a rare quiescent cell found within the ciliary epithelium (CE) of the mammalian eye ${ }^{1,2,3}$. The CE is made up of non-pigmented inner and pigmented outer cell layers, and the clonal RSC colonies that arise from a single pigmented cell from the CE are made up of both pigmented and non-pigmented cells which can be differentiated to form all the cell types of the neural retina and the RPE. There is some controversy about whether all the cells within the spheres all contain at least some pigment ${ }^{4}$; however the cells are still capable of forming the different cell types found within the neural retina ${ }^{1-3}$. In some species, such as amphibians and fish, their eyes are capable of regeneration after injury ${ }^{5}$, however; the mammalian eye shows no such regenerative properties. We seek to identify the stem cell in vivo and to understand the mechanisms that keep the mammalian retinal stem cells quiescent ${ }^{6-8}$, even after injury as well as using them as a potential source of cells to help repair physical or genetic models of eye injury through transplantation ${ }^{9-12}$. Here we describe how to isolate the ciliary epithelial cells from the mouse eye and grow them in culture in order to form the clonal retinal stem cell spheres. Since there are no known markers of the stem cell in vivo, these spheres are the only known way to prospectively identify the stem cell population within the ciliary epithelium of the eye.

\section{Video Link}

The video component of this article can be found at https://www.jove.com/video/2209/

\section{Protocol}

\section{Prepare the Dissecting Solutions and Enzyme Solutions}

1. Make the Artificial Cerebral Spinal Fluid (ACSF) and the Serum-free Media ahead of time and refrigerate.

2. Weigh out the Kynurenic Acid $(0.2 \mathrm{mg} / \mathrm{mL})$ and dissolve in $10 \mathrm{~mL}$ of hilo $A C S F$ in a $37^{\circ} \mathrm{C}$ waterbath ahead of time since it does not readily dissolve.

3. Weigh out the Trypsin $(1.33 \mathrm{mg} / \mathrm{mL})$ and Hyaluronidase $(0.67 \mathrm{mg} / \mathrm{mL})$ and place in one $15 \mathrm{~mL}$ tube and keep it at $-20^{\circ} \mathrm{C}$ until needed. Add the Kynurenic Acid solution to this tube and filter using a $22 \mu \mathrm{m}$ syringe filter just prior to use.

4. Weigh out Trypsin Inhibitor (Ovamucoid: $1 \mathrm{mg} / \mathrm{mL}$ ) and dissolve in warm Serum-free Media and filter using $22 \mu \mathrm{m}$ syringe filter

5. Make the plating media: Serum-free Media containing FGF2 $(10 \mathrm{ng} / \mathrm{mL})$ and Heparin $(2 \mu \mathrm{g} / \mathrm{mL})$.

\section{Isolating Retinal Stem Cells from the Mouse Eye}

1. Isolation of the retinal stem cells is performed in a specific sterile room dedicated to primary culture experiments. Prior to starting this procedure, set up the dissecting microscope and cold-light source, and then lay out the sterile dissecting instruments. Each hood has a hot bead sterilizer for sterilizing the instruments between steps.

2. We will isolate retinal stem cells from eyes that have been placed immediately in a sterile Petri dish containing Artificial Cerebral Spinal Fluid (ACSF) after their removal from mice sacrificed according to approved animal ethics protocols.

3. Under the dissecting microscope, clean the eye with forceps: get rid of the hair and the connective tissue that is attached to the cornea/scleral border. Then transfer the eye to a new dish with ACSF.

4. While gently holding the eye stationary with serrated forceps, use angled micro-dissecting scissors to remove the ocular muscles. Remove the optic nerve as well if it is still attached to the eye. Try not to squish the eye during this process. Transfer eyes to a new dish with ACSF.

5. Next use curved micro-dissecting scissors to cut the eye in half: begin at the optic nerve and cut through the middle of the cornea, meeting back at the optic nerve where the cut was initiated. It is ideal if the two pieces of eye are roughly equivalent in size because this will make the next step easier.

6. Holding the corneas using two forceps, gently peel the two eye halves apart. Remove and discard the lens, viscera, and the neural retinal from the eye shells. Transfer the shells to a new dish with ACSF.

7. Now we are ready to isolate the ciliary epithelium. To begin, orient the eye shell so that the cornea is on your right and the Retinal Pigmented Epithelium (RPE) is on the left. Gently pin the eye shell down with straight forceps on the RPE side. 
8. Next, use a scalpel to cut the cornea and iris away from the ciliary epithelium of the eye by gently pushing down on the scalpel rather than using sawing motions.

9. After that, cut the ciliary epithelium away from the RPE. Use non-serrated forceps to transfer the strip of ciliary epithelium to a new 35-mm dish containing ACSF.

10. In the same way, isolate the ciliary epithelium from the other eye shell.

11. Once both ciliary epithelial strips have been collected, transfer the strips into a 35-mm dish containing $2 \mathrm{~mL}$ of Dispase. Place the dish with the strips in a $37^{\circ} \mathrm{C}$ incubator for 10 minutes.

12. After 10 minutes, transfer the strips from the Dispase into a dish containing $2 \mathrm{~mL}$ of filtered Trypsin, Hyaluronidase, and Kynurenic Acid. Place the dish at $37^{\circ} \mathrm{C}$ for 10 minutes.

13. Now return to the dissecting microscope. While holding the sclera down with straight forceps, use the bottom of the curved non-serrated forceps to gently scrape the ciliary epithelium away from the sclera.

14. Remove the sclera from the dish. All that should be left in the dish now are the cells of interest and the enzyme solution.

15. Using a fire-polished cotton-plugged pipette, transfer this solution into a 14-ml tube. Triturate this solution 30 times to break apart the epithelial cells by gently forcing the solution in and out of the pipette.

16. Centrifuge the tube for 5 minutes at 1500 RPM. When the centrifugation is done, remove the tube from the centrifuge carefully since the cells are prone to coming off the bottom of the tube at this stage.

17. Gently aspirate the majority of the supernatant using a fire-polished pipette, and then add $1 \mathrm{~mL}$ of Trypsin inhibitor in Serum-free Media to the cells. Use a small borehole cotton-plugged pipette to triturate the sample approximately 50 times until it is a single-cell suspension.

18. Centrifuge the tube again for 5 minutes at 1500 RPM.

19. Remove the supernatant and replace it with $1 \mathrm{~mL}$ of your plating medium. Triturate gently using a fire-polished glass pipette to resuspend the cells.

20. After counting the cells, plate them at the desired density in a 24 -well plate. We usually plate 10 cells/ $\mu \mathrm{L}$ by filling each well first with medium and then adding the cell suspension to get a final volume of $500 \mu \mathrm{L}$ of media.

21. Place the plate in a $37^{\circ} \mathrm{C} \mathrm{CO}_{2}$ incubator where it will not be moved until you count the spheres that arise after 7 days.

\section{Results of Isolating Retinal Stem Cells}

1. When this procedure is performed successfully, the dissected ciliary epithelial cells should look like this after being dissociated and plated at low density (Figure 1).

2. After 7 days in culture, the retinal stem cell spheres that arise are counted. A sphere should be over $75 \mu \mathrm{m}$ in diameter and free-floating to be counted as a stem cell derived sphere. (Figure 2). However, some cells will have limited proliferation and form spheroids that do not meet size criterion and will not be counted as stem cell derived spheres; an example of such a spheroid is shown here (Figure 2).

\section{Representative Results}

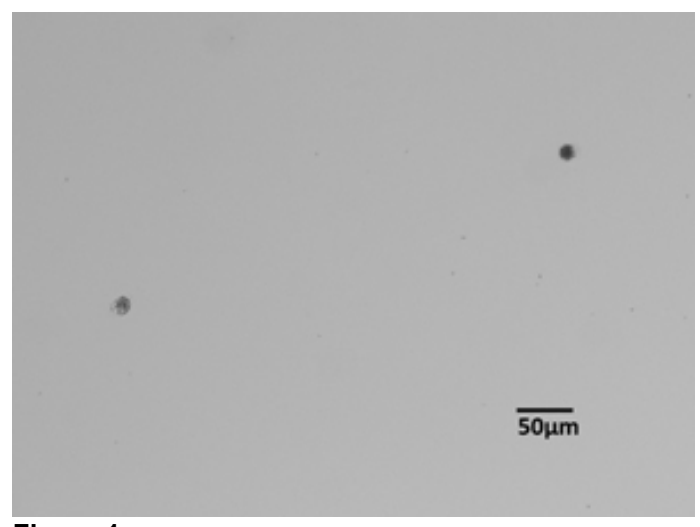

Figure 1. 


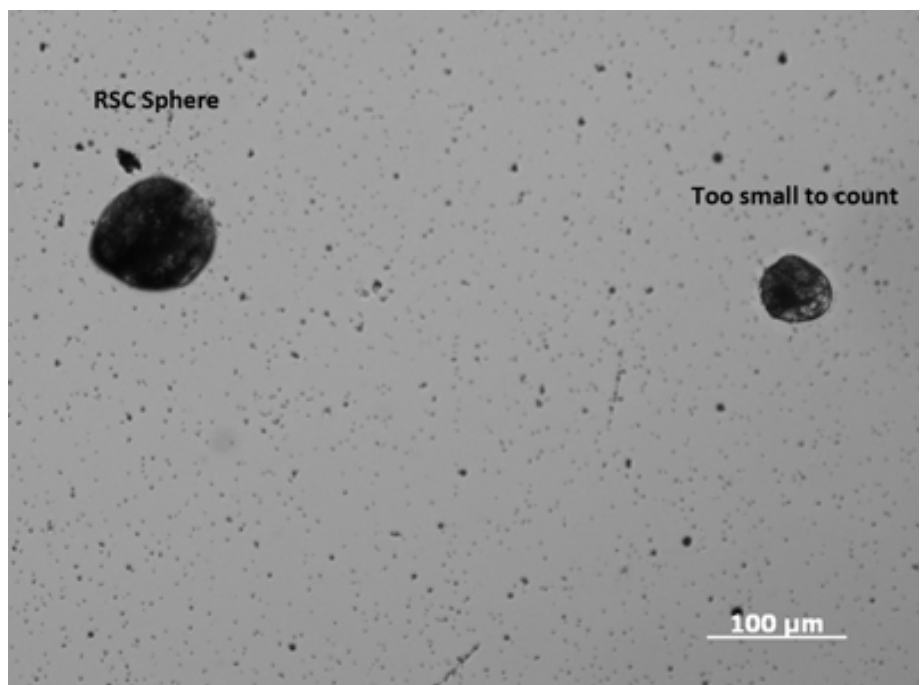

Figure 2.

\section{Discussion}

This protocol describes how to isolate retinal stem cells from the ciliary epithelium of the mouse eye ${ }^{1-3}$. The methodology for isolating the strips of ciliary epithelium can vary, however the enzymes and methodology for attaining a single-cell suspension have been optimized in this protocol. It is also important that the strips of ciliary epithelium that have been isolated do not contain large amounts of RPE or cornea since these appear to have a negative impact on the total number of spheres that can be isolated from each eye. In addition, the serum-free media that we make that was originally formulated for brain neurospheres ${ }^{13}$, is ideal for growing retinal stem cell spheres. One should also make sure that the cells are not disturbed after they have been plated and placed in the incubator so that the growing spheres do not aggregate together ${ }^{14}$.

Once the retinal stem cells have formed clonal spheres, they can be counted to get a prospective number of stem cells per eye. The spheres then can then be dissociated into single cells and passaged to ascertain self-renewal capabilities or differentiated into the different cell types of the neural retina and RPE using different combinations of growth factors and/or proteins.

\section{Disclosures}

No conflicts of interest declared.

\section{Acknowledgements}

We thank Laura Clarke for her invaluable assistance. This work is supported by NCE: Stem Cell Network, CIHR and NIH.

\section{References}

1. Tropepe, V., Coles, B. L., Chiasson, B.J. et al. Retinal stem cells in the adult mammalian eye. Science 287, 2032-2036 (2000).

2. Ahmad, I., Tang, L., Pham H. Identification of neural progenitors in the adult mammalian eye. Biochem Biophys Res Commun $270,517-521$ (2000).

3. Coles, B. L., Angenieux, B., Inoue, T. et al. Facile isolation and the characterization of human retinal stem cells. Proc Natl Acad Sci U S A 101, 15772-15777, (2004).

4. Cicero, S. A., Johnson, D., Reyntjens, S. et al. Cells previously identified as retinal stem cells are pigmented ciliary epithelial cells. Proc Nat Acad Sci U S A 106: 6685-6690 (2009).

5. Lamba, D., Karl, M., Reh T. Neural regeneration and cell replacement: a view from the eye. Cell Stem Cell 2(6), 538-49 (2008).

6. Coles, B. L., Horsford, D. J., McInnes, R. R., van der Kooy, D. Loss of retinal progenitor cells leads to an increase in the retinal stem cell population in vivo. Eur J Neurosci 23, 75-82 (2006).

7. Angénieux, B., Schorderet, D. F., Arsenijevic, Y. Epidermal growth factor is a neuronal differentiation factor for retinal stem cells in vitro. Stem Cells 24(3), 696-706 (2006).

8. Xu, S., Sunderland, M. E., Coles, B.L. et al. The proliferation and expansion of retinal stem cells require functional Pax6. Dev Biol 304, 713-721 (2007).

9. Canola, K., Angénieux, B., Tekaya, M., Quiambao, A., Naash, M. I., Munier, F. L., Schorderet, D. F., Arsenijevic, Y. Retinal stem cells transplanted into models of late stages of retinitis pigmentosa preferentially adopt a glial or a retinal ganglion cell fate. Invest Ophthalmol Vis Sci 48(1), 446-54 (2007).

10. Canola, K., Arsenijevic Y. Generation of cells committed towards the photoreceptor fate for retinal transplantation. Neuroreport 18(9), 851-5 (2007).

11. Djojosubroto, M. W., Arsenijevic Y. Retinal stem cells: promising candidates for retina transplantation. Cell Tissue Res 331(1), 347-57 (2008). 
12. Inoue, T., Coles, B. L., Dorval, K., Bremner, R., Bessho, Y., Kageyama, R., Hino, S., Matsuoka, M., Craft, C. M., Mclnnes, R. R., Tremblay, F., Prusky, G. T., van der Kooy, D. Maximizing functional photoreceptor differentiation from adult human retinal stem cells. Stem Cells 28(3), 489-500 (2010).

13. Tropepe, V., Sibilia, M., Ciruna, B. G., Rossant, J., Wagner, E. F., van der Kooy, D. Distinct neural stem cells proliferate in response to EGF and FGF in the developing mouse telencephalon. Dev Biol 208(1),166-88 (1999).

14. Coles-Takabe, BL., Brain, I., Purpura, KA., Karpowicz, P., Zandstra, PW., Morshead, C.M., van der Kooy, D. Don't look: growing clonal versus nonclonal neural stem cell colonies. Stem Cells 26(11), 2938-44 (2008). 